\title{
Article \\ Synthesis of Carbon-Supported PdIrNi Catalysts and Their Performance towards Ethanol Electrooxidation
}

\author{
Ahmed Elsheikh ${ }^{1,2, *(\mathbb{D}, \text { Hamouda M. Mousa }}{ }^{2}$ (D) and James McGregor ${ }^{2}$ (D) \\ 1 Chemical and Biological Engineering Department, University of Sheffield, Sheffield S1 3JD, UK \\ 2 Mechanical Engineering Department, South Valley University, Qena 83523, Egypt; \\ hmousa@eng.svu.edu.eg (H.M.M.); james.mcgregor@sheffield.ac.uk (J.M.) \\ * Correspondence: ahmed.elsheikh@eng.svu.edu.eg
}

Citation: Elsheikh, A.; Mousa, H.M.;

McGregor, J. Synthesis of

Carbon-Supported PdIrNi Catalysts and Their Performance towards

Ethanol Electrooxidation.

Micromachines 2021, 12, 1327. https://

doi.org $/ 10.3390 / \mathrm{mi} 12111327$

Academic Editor: Hong Li

Received: 10 September 2021

Accepted: 25 October 2021

Published: 28 October 2021

Publisher's Note: MDPI stays neutral with regard to jurisdictional claims in published maps and institutional affiliations.

Copyright: (C) 2021 by the authors. Licensee MDPI, Basel, Switzerland. This article is an open access article distributed under the terms and conditions of the Creative Commons Attribution (CC BY) license (https:/ / creativecommons.org/licenses/by/ $4.0 /)$.

\begin{abstract}
Direct ethanol fuel cells (DEFCs) have shown a high potential to supply energy and contribute to saving the climate due to their bioethanol sustainability and carbon neutrality. Nonetheless, there is a consistent need to develop new catalyst electrodes that are active for the ethanol oxidation reaction (EOR). In this work, two C-supported PdIrNi catalysts, that have been reported only once, are prepared via a facile $\mathrm{NaBH}_{4}$ co-reduction route. Their physiochemical characterization (X-ray diffraction (XRD), transmission electron microscopy (TEM), energy-dispersive $X$-ray spectroscopy (EDX), and X-ray photoelectron spectroscopy (XPS)) results show alloyed PdIrNi nanoparticles that are well dispersed $(<3 \mathrm{~nm})$ and exist in metallic state that is air-stable apart from Ni and, slightly, Pd. Their electrocatalytic activity towards EOR was evaluated by means of cyclic voltammetry (CV) and chronoamperometry (CA). Even though the physiochemical characterization of PdIrNi/C and $\mathrm{Pd}_{4} \mathrm{Ir}_{2} \mathrm{Ni}_{1} / \mathrm{C}$ is promising, their EOR performance has proven them less active than their $\mathrm{Pd} / \mathrm{C}$ counterpart. Although the oxidation current peak of $\mathrm{Pd} / \mathrm{C}$ is $1.8 \mathrm{~A} / \mathrm{mgPd}$, it is only $0.48 \mathrm{~A} / \mathrm{mgPd}$ for $\mathrm{Pd}_{4} \mathrm{Ir}_{2} \mathrm{Ni}_{1} / \mathrm{C}$ and $0.52 \mathrm{~A} / \mathrm{mg}_{\mathrm{Pd}}$ for $\mathrm{PdIrNi} / \mathrm{C}$. These results were obtained three times and are reproducible, but since they do not add up with the sound PdIrNi microstructure, more advanced and in situ EOR studies are necessary to better understand the poor EOR performance.
\end{abstract}

Keywords: supported intermetallic nanoparticles; alloy formation; surface microstructure; ethanol oxidation

\section{Introduction}

With the consequences of growing climate change and consistent worldwide energy demand, there is an urgent need to find alternative energy sources and technologies that are sustainable and friendly to the environment [1-3]. Fuel cells are one of the promising technologies which can contribute to energy demands while mitigating environmental challenges by reduction of greenhouse gas (GHG) emissions unlike conventional heat engines [4-7]. Direct application of ethanol into the fuel cell anode is a recent crucial direction in the research community. One of its advantages, as a liquid, ethanol is easy to store and transport. Moreover, it is energetic $(8 \mathrm{kWh} / \mathrm{L})$, and can be produced from biomass and agricultural sources [8,9]. Also, it is less likely than methanol to crossover the membrane from the anode to the cathode. Furthermore, it is also less toxic than methanol. Consequently, the development of direct ethanol fuel cells (DEFCs) is a promising research goal [9-12]. Despite those advantages, there remain challenges regarding the commercialization of DEFCs. One is the scarcity of Pt reserves [13,14]. Applying an alkaline medium instead of acidic one has shown advantages for the overall fuel cell performance and cost because it improves the reaction kinetics, enables using lessor non-noble metal catalyst, and provides a less corrosive environment $[9,15]$. To prepare the fuel cell catalyst, an inert and high surface-area support material is usually required to disperse the small metal nanoparticles and maximize the reaction area. Carbon materials such as vulcan carbon, carbon nanotubes, nanofibers, and graphene are the most common support materials that have been studied [16-23]. Furthermore, achieving lower metal 
loading and consumption and attaining dispersed metal species are other benefits of using a carbon support [24].

Pt can be replaced by Pd which is very similar to Pt but more abundant in the Earth. Another advantage is the higher Pd tolerance towards catalyst poisons (e.g., $\mathrm{CO}_{\mathrm{x}}$ species) while Pt is highly susceptible to poisoning and its functional life ends quickly [13,25-27]. Furthermore, adding a second metal as a cocatalyst is technoeconomically beneficial because it decreases the noble metal consumption and can modify the electronic and geometric properties of Pd nanoparticles [28-30]. Among the metals that could promote Pd electrocatalytic activity towards EOR are $\mathrm{Ni}, \mathrm{Sn}, \mathrm{Ir}, \mathrm{Au}$, and $\mathrm{Cu}$ [5,31-34]. However, even with the bimetallic benefits, still a further improvement in the performance and reduction in cost are necessary to enable wider exploitation of DEFCs. Some groups have investigated the synthesis of trimetallic systems instead of bimetallic ones in order to maximize the technoeconomic benefits of co-catalyst metals added to Pd or Pt [4,12,32,35-40]. Adding Ir $[2,6,33]$ or $\mathrm{Ni}[10,30,41,42]$ as a cocatalyst into $\mathrm{Pd} / \mathrm{C}$ is proven to be beneficial towards EOR. The hypothesis of this work is that adding both Ir and $\mathrm{Ni}$ to $\mathrm{Pd} / \mathrm{C}$ would multiply the catalytic promotion towards EOR more than the single addition of Ir or Ni. As far as the authors are concerned, only one similar work [4] of PdIrNi/C trimetallic systems has been reported in which the PdIrNi/C has outperformed its Pd/C, PdIr/C, and PdNi/C counterparts towards EOR.

\section{Materials and Methods}

The synthesis of the anodic tri-metallic catalysts in the present study followed the previously reported works $[33,43,44]$ with minor modification. All chemicals were purchased from Sigma-Aldrich (Gillingham, UK) except vulcan carbon which was purchased from Capot Corp (Boston, MA, USA). Table 1 shows the stoichiometric added quantities of metal and carbon precursors to each respective sample. To prepare the catalysts, the respective metal and carbon precursors were mixed in a mixture of 2-propanol and water $(50 / 50, v / v)$. Then, $\mathrm{KBr}$ was added as a capping agent with an atomic $\mathrm{KBr} /$ metal ratio of 1.5:1. The mixture was stirred for 20 min before the $\mathrm{NaBH}_{4}$ solution $(0.5 \mathrm{M}, 15 \mathrm{~mL})$ was added under stirring. It was, subsequently, kept under stirring for $30 \mathrm{~min}$. Finally, the catalyst was copiously washed in deionized water and vacuum filtered and dried in a vacuum oven at $120^{\circ} \mathrm{C}$ for $2 \mathrm{~h}$.

Table 1. Nominal added metal and carbon precursors to prepare $\mathrm{Pd} / \mathrm{C}, \mathrm{PdIrNi} / \mathrm{C}$, and $\mathrm{Pd}_{4} \mathrm{Ir}_{2} \mathrm{Ni}_{1} / \mathrm{C}$.

\begin{tabular}{ccccc}
\hline Catalyst & $\mathbf{C}(\mathbf{m g})$ & $\left.\mathbf{P d C l}_{\mathbf{2}} \mathbf{( m g}\right)$ & $\left.\mathbf{N i C l}_{\mathbf{2}} \mathbf{( m g}\right)$ & $\mathbf{I r C l}_{\mathbf{3}} \mathbf{( \mathbf { m g } )}$ \\
\hline $\mathrm{Pd} / \mathrm{C}$ & 132 & 29.4 & - & - \\
$\mathrm{PdIrNi} / \mathrm{C}$ & 132 & 8.83 & 6.46 & 14.94 \\
$\mathrm{Pd}_{4} \mathrm{Ir}_{2} \mathrm{Ni}_{1} / \mathrm{C}$ & 132 & 14.19 & 2.58 & 11.94 \\
\hline
\end{tabular}

The crystal structure was examined by X-ray diffraction (XRD) utilising a Bruker D2 Phaser (Billerica, MA, USA) operating at $30 \mathrm{~mA}$ and a scan rate of $12^{\circ} / \mathrm{min}$. Transmission electron microscopy (TEM) was performed to study the surface morphology, particle shape, and size distribution using a Philips/FEI CM 100 microscope (Hillsboro, OR, USA) operating at $100 \mathrm{kV}$ with a LaB6 filament. The TEM samples were prepared by spraying $20 \mu \mathrm{L}$ of the catalyst slurry (powder + ethanol) over the C-coated $\mathrm{Cu}$ grids which were then left to dry overnight. The elemental composition was examined by an X-ray spectroscopy (EDX) detector attached to a JEOL 6010A scanning electron microscope (Akishima, Tokyo, Japan). Two accelerating voltages of $10 \mathrm{kV}$ and $20 \mathrm{kV}$ were applied to investigate the composition at varying depths from the surface [45]. The valence state and top-surface composition were examined by X-ray photoelectron spectroscopy (XPS) using a Thermo Fisher Scientific K-alpha + spectrometer (Waltham, MA, USA). A monochromatic Al X-ray source $(72 \mathrm{~W})$ was used to analyse samples over $400 \mu \mathrm{m}^{2}$ of area. Data were recorded at $120-\mathrm{eV}$ and $40-\mathrm{eV}$ pass energies for the survey and high-resolution scan, respectively. Data analysis was performed in CasaXPS from Casa Software Ltd. (Teignmouth, UK) and using a Shirley type background and Scofield cross sections, with an energy dependence of -0.6 . 
To evaluate the catalyst performance towards ethanol electrooxidation, cyclic voltammetry (CV) and chronoamperometry (CA) tests were performed in a home-made three-electrode half-cell. A Gamry reference 600 mini-station from Gamry Instruments Inc. (Warminster, PA, USA) was used to evaluate the performance. The working electrode was a glassy carbon electrode $(\phi 3 \mathrm{~mm})$ onto which the catalyst ink slurry $(25 \mu \mathrm{L})$ was drop-casted and dried. That slurry was prepared by dispersing $5 \mathrm{mg}$ of each catalyst powder in a mixture of ethanol $(2 \mathrm{~mL})$ and Nafion ${ }^{\circledR} 1175 \mathrm{wt} . \%(25 \mu \mathrm{L})$ followed by $1 \mathrm{~h}$ of stirring. The reference and counter electrode were $\mathrm{Ag} / \mathrm{AgCl}$ (sat' $\mathrm{KCL}$ ) and $\mathrm{Pt}$ wire, respectively. The reference electrode potential was converted to normal hydrogen electrode (NHE) in the voltammograms. To facilitate the reactant mass diffusion across the electrode-electrolyte interface, the electrochemical tests were performed in magnetically stirred solutions at a speed of $50 \mathrm{rpm}$.

\section{Results}

Figure 1 shows the XRD patterns of $\mathrm{PdIrNi} / \mathrm{C}, \mathrm{Pd}_{4} \mathrm{Ir}_{2} \mathrm{Ni}_{1} / \mathrm{C}, \mathrm{Pd} / \mathrm{C}, \mathrm{Ni} / \mathrm{C}$, and $\mathrm{Ir} / \mathrm{C}$. The broad peak at $\sim 25^{\circ}$ is attributed to the semi-crystalline nature of graphitic vulcan carbon. The basal C (002) peak is broader than the other metallic peaks in $\mathrm{Pd} / \mathrm{C}, \mathrm{Ir} / \mathrm{C}$, $\mathrm{Pd}_{4} \mathrm{Ir}_{2} \mathrm{Ni}_{1} / \mathrm{C}$ and PdIrNi/C. However, it is more intense in the case of Ni/C, probably because small-size oxidized Ni species are the main constituent, but the peak at approximately $43^{\circ}$ seems to represent the $f c c$ metallic Ni peak of (111) according to [30,46]. The other peaks of $\mathrm{Ni} / \mathrm{C}$ at $\sim 35^{\circ}$, and $\sim 60^{\circ}$ are attributed to nickel hydroxide species according to the same references. Considering the $\mathrm{Pd} / \mathrm{C}$ pattern, this shows another three peaks located at approximately $40^{\circ}, 46^{\circ}, 67.8^{\circ}$, and $82.3^{\circ}$ ascribed to the Pd polycrystalline phases of Pd (111), Pd (200), Pd (220), and Pd (311), respectively. Similar peaks to those exist-but positively shifted $1^{\circ}$ in the case of $\mathrm{Ir} / \mathrm{C}$-due to the smaller crystal lattice size and atomic radius of Ir compared to $\mathrm{Pd}$.

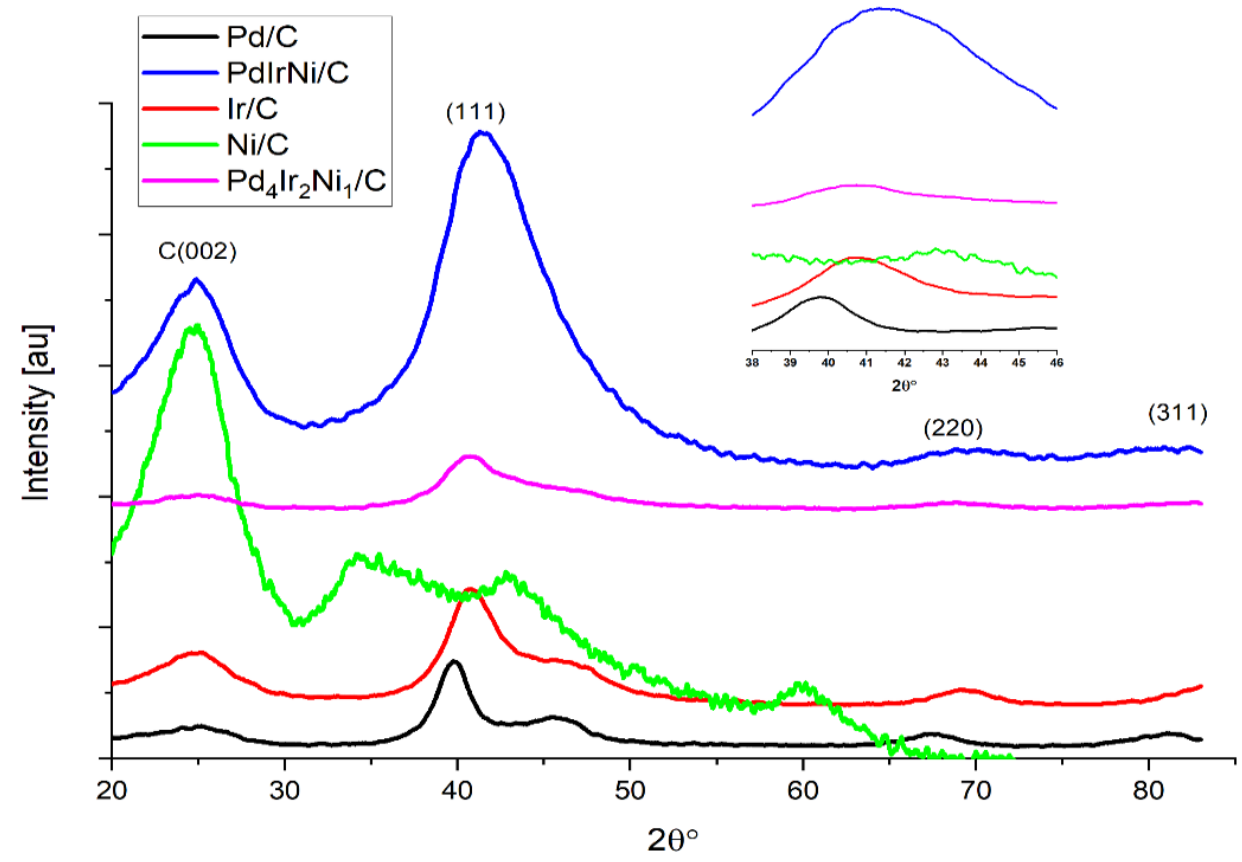

Figure 1. X-ray diffraction (XRD) patterns of $\mathrm{Pd} / \mathrm{C}, \mathrm{Ir} / \mathrm{C}, \mathrm{Ni} / \mathrm{C}, \mathrm{Pd}_{4} \mathrm{Ir}_{2} \mathrm{Ni}_{1} / \mathrm{C}$ and $\mathrm{PdIrNi} / \mathrm{C}$, inset figure: an enlarged (111) peak.

As for PdIrNi/C and $\mathrm{Pd}_{4} \mathrm{Ir}_{2} \mathrm{Ni}_{1} / \mathrm{C}$ catalysts, it can be noted that the presence of $\mathrm{Ir}$ and $\mathrm{Ni}$ has shifted the XRD peaks to higher angle values towards pure Ir pattern. This shift is demonstrated in the inset graph in Figure 1 which shows the PdIrNi is reflected at angles close to those of pure Ir which was also noted in [4,33]. According to [33], the lower $d$-space $\operatorname{Ir}\left(\mathrm{d}_{111}=2.217 \AA\right)$ could be incorporated into the larger $d$-space Pd $\left(\mathrm{d}_{111}=2.217 \AA\right)$ and form an alloy regardless of their atomic proportions. The crystal lattice 
of $\mathrm{Pd}$, therefore, might be subjected to compressive stresses and strains that have resulted in lattice contraction in the trimetallic samples. Also, peak broadening in the case of PdIrNi/C is higher than that of $\mathrm{Pd} / \mathrm{C}$ and $\mathrm{Ir} / \mathrm{C}$ which could be explained by the decreasing particle size. Notably, the $\mathrm{Ni}(\mathrm{OH})_{2}$ peaks at $35^{\circ}$ and $60^{\circ}$ that have been reported in Ni-containing trimetallic and bimetallic catalysts $[30,46]$ are suppressed in the PdIrNi/C diffractogram. This implies a good overall mixing of the three metals and that an alloy of Pd, Ir, and Ni was formed. The crystallite size $(\tau, \mathrm{nm})$ is estimated using the Scherrer's Equation (1) and the catalyst respective sizes are listed in Table 2 which shows a significant particle size reduction from $4 \mathrm{~nm}$ for the monometallic $\mathrm{Pd} / \mathrm{C}$ to 1.4 and $1.8 \mathrm{~nm}$ for PdIrNi/C and $\mathrm{Pd}_{4} \mathrm{Ir}_{2} \mathrm{Ni}_{1} / \mathrm{C}$, respectively.

$$
\tau=\frac{K \lambda}{\beta \cos (\theta)}
$$

where, $K$ is constant (0.94), $\lambda$ is wavelength of $\mathrm{Cu}$ and equals $0.154 \mathrm{~nm}, \beta$ is the is the full width at half-maximum height in radians, $\theta$ is half of the diffraction angle. Table 2 also lists the estimated lattice constant for $\mathrm{Pd} / \mathrm{C}, \mathrm{PdIrNi} / \mathrm{C}$, and $\mathrm{Pd}_{4} \mathrm{Ir}_{2} \mathrm{Ni}_{1} / C$. The pure Pd lattice constant is approximately $3.89 \AA$ [47], but as shown in Table 2, the C-supported Pd lattice constant is 0.11 - $\AA$ larger. This expansion in the Pd lattice is possibly due to the interaction between $\mathrm{Pd}$ and $\mathrm{C}$ support during synthesis. This interaction exercises a tensile strain on the Pd crystal lattice. Adding Ni and Ir in PdIrNi/C leads to $0.3-\AA$ reduction in the lattice constant which could be attributed to the replacement of some Pd atoms by Ir and $\mathrm{Ni}$ ones in the formed alloy. While maintaining the metal loading rate $12 \mathrm{wt} \%$, decreasing the Ir and $\mathrm{Ni}$ content added to $\mathrm{Pd}$ in $\mathrm{Pd}_{4} \mathrm{Ir}_{2} \mathrm{Ni}_{1} / \mathrm{C}$ results in less reduction $(0.2 \AA)$ of the $\mathrm{Pd}$ constant lattice which, also, could be the result of $\mathrm{Ir}$ and $\mathrm{Ni}$ atoms replacing Pd ones. According to [47], the lattice constants of Ir and Ni are 3.84 and $3.52 \AA$, respectively.

Table 2. Crystallographic and tomographic information of $\mathrm{Pd} / \mathrm{C}, \mathrm{PdIrNi} / \mathrm{C}$, and $\mathrm{Pd}_{4} \mathrm{Ir}_{2} \mathrm{Ni}_{1} / \mathrm{C}$.

\begin{tabular}{|c|c|c|c|c|}
\hline Catalyst & XRD * Size $(\mathrm{nm})$ & Lattice Constant $(\AA ̊)$ & TEM ** Size $(\mathrm{nm})$ & \% Dispersion \\
\hline $\mathrm{Pd} / \mathrm{C}$ & 4 & 4 & 5 & 25 \\
\hline PdIrNi/C & 1.4 & 3.7 & 1.9 & 52 \\
\hline $\mathrm{Pd}_{4} \mathrm{Ir}_{2} \mathrm{Ni}_{1} / \mathrm{C}$ & 1.8 & 3.8 & 2.3 & 44 \\
\hline
\end{tabular}

* XRD: X-ray Diffraction. ** TEM: Transmission Electron Microscopy.

To investigate the composition of the trimetallic system and metal load on carbon, energy-dispersive X-ray spectroscopy (EDX) was performed at two different accelerating voltages aiming to vary to the depth at which the composition is analysed [45]. Table 3 shows the weight concentration of each metal at $10 \mathrm{kV}$ and $20 \mathrm{kV}$. The metal loading values are close but slightly higher that the nominal loads of $12 \mathrm{wt} . \%$. This might be attributed to two reasons: first the electron beam used in EDX analysis does not travel through the sample but is reflected after penetrating a certain depth from the top surface and, therefore, does not analyse the bulk composition [45]. Secondly, the metal particle surface energy could have exercised a segregation potential which is more obvious in the higher Ni-containing PdIrNi since Ni has a significant tendency to segregate into the surface [42]. Furthermore, both samples metal load at $10 \mathrm{kV}$ is higher than that at $20 \mathrm{kV}$ which incorporates the metal nanoparticle tendency to segregate into the surface.

Table 3. Elemental energy-dispersive X-ray spectroscopy (EDX) compositional analysis and metal loading (wt.\%) of the $\mathrm{PdIrNi} / \mathrm{C}$ and $\mathrm{Pd}_{4} \mathrm{Ir}_{2} \mathrm{Ni}_{1} / \mathrm{C}$ surfaces.

\begin{tabular}{lcccccccc}
\hline Catalyst & Acc. Voltage & \multicolumn{2}{c}{ Pd } & \multicolumn{2}{c}{ Ni } & & Ir & \multicolumn{2}{c}{ Metal Load (wt.\%) } \\
\hline & & wt. $\%$ & at.\% & wt.\% & at.\% & wt.\% & at. \% & \\
\hline \multirow{2}{*}{$\mathrm{PdIrNi} / \mathrm{C}$} & $10 \mathrm{kV}$ & 5.75 & 0.41 & 4.86 & 1.14 & 7.40 & 0.41 & 18 \\
\multirow{2}{*}{$\mathrm{Pd}_{4} \mathrm{Ir}_{2} \mathrm{Ni}_{1} / \mathrm{C}$} & $20 \mathrm{kV}$ & 5.36 & 0.62 & 2.51 & 0.53 & 6.62 & 0.39 & 14.5 \\
& $10 \mathrm{kV}$ & 7.15 & 0.97 & 1.15 & 0.28 & 6.95 & 0.52 & 15.3 \\
\hline
\end{tabular}


Figure 2 shows the EDX elemental spectrum of PdIrNi at $20 \mathrm{kV}$. The predominantly high $\mathrm{C}-\mathrm{K}$ peak is not shown in order not to suppress the other metallic ones. The peaks of $\mathrm{Ir}-\mathrm{M}, \mathrm{Pd}-\mathrm{L}$, and $\mathrm{Ni}-\mathrm{K}$ are all visible in the spectrum. The $\mathrm{Na}, \mathrm{S}$, and $\mathrm{Si}$ peaks could be ascribed to the Vulcan carbon impurities. The $\mathrm{O}-\mathrm{K}$ one is probably due to either the carbon functional groups or $\mathrm{Ni}$ oxide species. It is noteworthy that $\mathrm{Ni}$ concentration at $10 \mathrm{kV}$ is almost twice its concentration at $20 \mathrm{kV}$ for both trimetallic samples; a trend that is not noted for both Pd and Ir. This finding is crucial because it proves the high surface segregation potential of $\mathrm{Ni}[42,46]$. Another important observation from Table 3 is that both Pd and Ir concentrations in both samples measured at $10 \mathrm{kV}$ are higher than those at $20 \mathrm{kV}$, but the Ir increase is higher than that of Pd which shows the Ir's higher tendency of surface segregation. Figure 3 shows the EDX elemental maps of PdIrNi/C and $\mathrm{Pd}_{4} \mathrm{Ir}_{2} \mathrm{Ni}_{1} / \mathrm{C}$ recorded at $20 \mathrm{kV}$. The Ir and Pd maps of PdIrNi/C (Figure 3A,B) show more densely populated samples as compared to Ni (Figure 3C). The less dense population of $\mathrm{Ni}$ map is due to the lower atomic Ni concentration detected compared to Pd and Ir (Table 3) even though the nominal added quantities of the three metals are equivalent. This is probably because Ni tends to segregate to a higher surface level above the EDX electron beam interaction volume which is supported by the significant XPS surface concentration (Table 4$)$ of $\mathrm{Ni}$ (1.25 at.\%) that is higher than Pd (1.21 at.\%) but lower than that of Ir (1.48 at.\%). A similar trend could be observed for $\mathrm{Pd}_{4} \mathrm{Ir}_{2} \mathrm{Ni}_{1} / \mathrm{C}$ sample (Figure 3D,E,G).

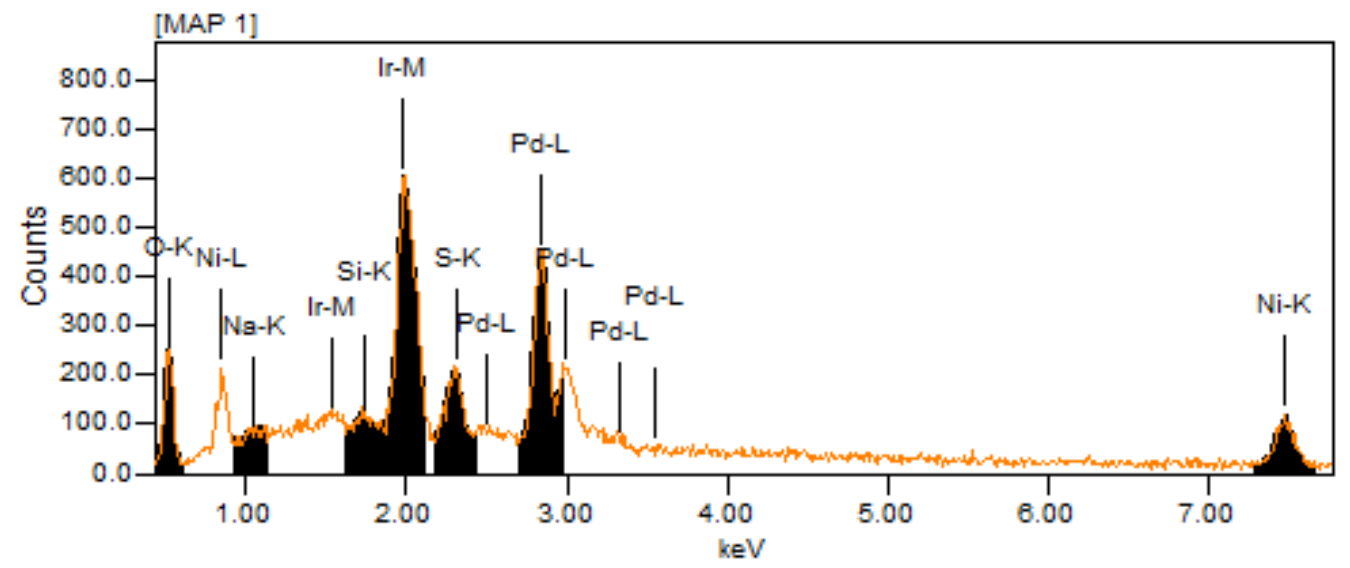

Figure 2. EDX elemental spectrum at $20 \mathrm{kV}$ of PdIrNi.
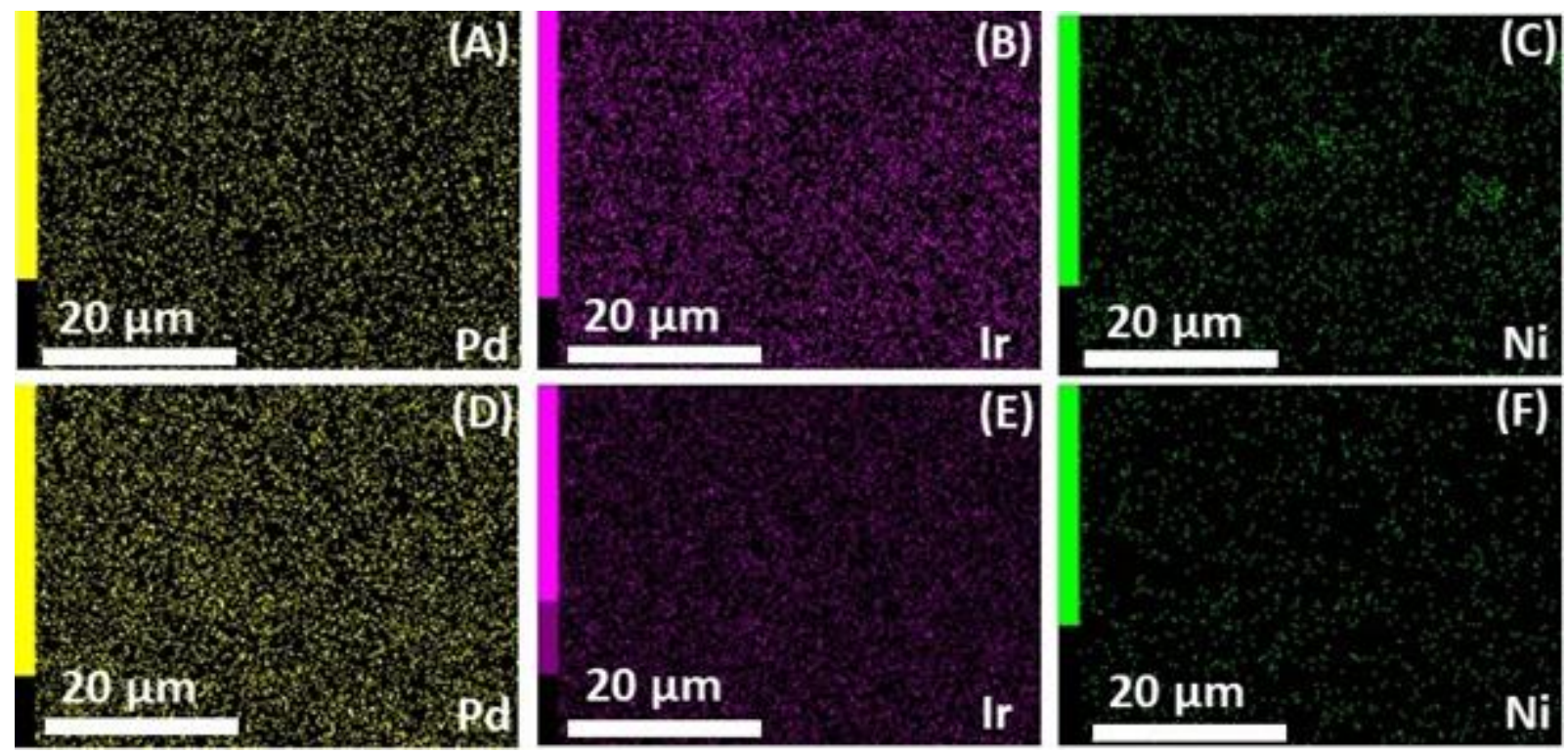

Figure 3. EDX Pd, Ir, and Ni maps of PdIrNi/C (A-C) and $\mathrm{Pd}_{4} \mathrm{Ir}_{2} \mathrm{Ni}_{1} / \mathrm{C}(\mathbf{D}-\mathrm{F})$. 
Table 4. X-ray photoelectron spectroscopy (XPS) data of valence state and metal/oxide atomic concentration measurements in $\mathrm{Pd} / \mathrm{C}, \mathrm{Pd}_{4} \mathrm{Ir}_{2} \mathrm{Ni}_{1} / \mathrm{C}$ and $\mathrm{PdIrNi} / \mathrm{C}$.

\begin{tabular}{|c|c|c|c|c|c|c|c|c|c|}
\hline \multirow{2}{*}{ Catalyst } & \multicolumn{2}{|c|}{ Pd at. \% } & \multirow{2}{*}{$P d 3 d_{5 / 2}(e V)$} & \multirow{2}{*}{ C at. $\%$} & \multirow{2}{*}{ Ir at. $\%$} & \multirow{2}{*}{$\operatorname{Ir} 4 f_{7 / 2}(e V)$} & \multicolumn{2}{|c|}{$\mathrm{Ni}$ at. $\%$} & \multirow{2}{*}{$\mathrm{Ni} 2 \mathrm{p}_{3 / 2}(\mathrm{eV})$ * } \\
\hline & $\mathbf{P d}^{0}$ & $\mathbf{P d}^{2+}$ & & & & & $\mathrm{Ni}^{0}$ & $\mathrm{Ni}^{2+}$ & \\
\hline $\mathrm{Pd} / \mathrm{C}$ & 1.63 & 0.45 & 335.43 & 96.13 & $x$ & $x$ & $x$ & $x$ & $\mathrm{x}$ \\
\hline PdIrNi/C & 1.18 & 0.13 & 335.54 & 91.09 & 1.48 & 60.88 & 0.32 & 0.93 & 852.74 \\
\hline $\mathrm{Pd}_{4} \mathrm{Ir}_{2} \mathrm{Ni}_{1} / \mathrm{C}$ & 1.39 & 0.10 & 335.51 & 93.62 & 1.16 & 60.98 & 0.12 & 0.18 & 852.6 \\
\hline
\end{tabular}

* The location of $\mathrm{Ni}^{2+}$.

To study the nanocatalyst surface morphology, transmission electron microscopy (TEM) was performed. Figure 4 shows the micrographs and particle size distribution of $\mathrm{Pd} / \mathrm{C}$ (A), PdIrNi/C (B) and $\mathrm{Pd}_{4} \mathrm{Ir}_{2} \mathrm{Ni}_{1} / \mathrm{C}$ (D). For Pd/C, dispersed metal dark particles $(2-10 \mathrm{~nm})$ appear along larger grey carbon aggregates $(30-60 \mathrm{~nm})$. Nonetheless, particle agglomeration could be seen for this sample. Intense aggregated particles are visible in the middle area but this is, probably, due to the TEM sample preparation and not something inherent in the $\mathrm{Pd} / \mathrm{C}$ powder. The particle size distribution of that sample shows the average particle size (of approximately 100 particles) equals $5 \mathrm{~nm}$ which is close to but larger than the XRD size (Table 2). Figure 4B shows the micrograph and particle size distribution of $\mathrm{PdIrNi} / \mathrm{C}$ which shows enhanced particle dispersion compared to $\mathrm{Pd} / \mathrm{C}$ (Figure 4A). The average particle size of PdIrNi is $1.9 \mathrm{~nm}$ which is $3.1 \mathrm{~nm}$ smaller than Pd. Likewise, the particle size of $\mathrm{Pd}_{4} \mathrm{Ir}_{2} \mathrm{Ni}_{1}$ (Figure 4C) equals $2.3 \mathrm{~nm}$ which is $2.7 \mathrm{~nm}$ less than Pd but $0.4 \mathrm{~nm}$ larger than PdIrNi. The TEM analysis showed significant particle size reduction in the trimetallic samples compared to $\mathrm{Pd} / \mathrm{C}$. This is a usual finding when preparing bimetallic and trimetallic supported nanoparticles due to difference in metal chemistries [41,48,49]. Another reason for the trimetallic particle size decrease of PdIrNi is that since the geometrical parameters of Ir and $\mathrm{Ni}$ are smaller than those of $\mathrm{Pd}$, they are likely to be incorporated into the latter's lattice exercising compressive stress and strain causing a net lattice contraction. As shown in Figure 1, adding Ir to Pd shifts its diffraction angles to higher values and exercise compressive strain on it. The increase of particle size of $\mathrm{Pd}_{4} \mathrm{Ir}_{2} \mathrm{Ni}_{1}$ compared to $\mathrm{PdIrNi}$ is, probably, due to the decreased proportion of $\mathrm{Ni}$ and $\mathrm{Ir}$ and increased one of $\mathrm{Pd}$ in the former since the overall metal load is unchanged.

The electrocatalyst dispersion $\left(\% N_{S} / N_{T}\right)$ could be estimated by applying the Van del Klink Equations (2)-(4) [42]:

$$
\begin{gathered}
N_{T}=\frac{2 \pi}{3} \times\left(\frac{d}{a}\right)^{3} \\
N_{T}=\frac{10}{3} l^{3}-5 l^{2}+\left(\frac{11}{3}\right) l-1 \\
N_{S}=10 l^{2}-20 l+12
\end{gathered}
$$

where, $N_{T}$ is the total number of atoms, $d$ is the average TEM particle size (nm), $a$ is the lattice constant, $l$ is the number of layers and $N_{S}$ is the number of surface atoms. As listed in Table 2, the lowest dispersion is that of $\mathrm{Pd} / \mathrm{C}$ followed by $\mathrm{Pd}_{4} \mathrm{Ir}_{2} \mathrm{Ni}_{1} / \mathrm{C}$ and $\mathrm{PdIrNi} / \mathrm{C}$ is the highest in particle dispersion as listed in (Table 2).

To study the valence state and further examine the surface composition, XPS analysis was performed. Figure 5 shows the full XPS surveys of $\mathrm{Pd} / \mathrm{C}, \mathrm{Pd}_{4} \mathrm{Ir}_{2} \mathrm{Ni}_{1} / \mathrm{C}$, and $\mathrm{PdIrNi} / \mathrm{C}$. The global and most intense peak at $284 \mathrm{eV}$ represents the carbon 1s peak. Additionally, the peaks of $\mathrm{Ir} 4 \mathrm{f}, \mathrm{Pd} 3 \mathrm{~d}$, and Ni $2 \mathrm{p}$ are located at approximately 62,335 , and $858 \mathrm{eV}$, respectively. Figure $6 \mathrm{C}$ shows the enlarged $\mathrm{C} 1 \mathrm{~s}$ peak which shows the predominant component of vulcan carbon is hybridised $\mathrm{sp}^{2}$. In the three sample spectra, there is an overlap between the peaks of $\mathrm{Pd} 3 \mathrm{~d}$ and $\mathrm{O} 1 \mathrm{~s}$ which is shown in Figure 6C. Table 4 shows the atomic concentration of each metal and its oxide form in addition to the binding energy value that is distinctive to each metal. Also, the details of elemental peaks of $\mathrm{Pd}$, Ir, and $\mathrm{Ni}$ in the three samples are shown in Figure 6. The Pd 3d peak of Pd/C is shown in Figure 6A and it is deconvoluted into high- and low-energy bands. The lower-energy $\mathrm{Pd} 3 \mathrm{~d}_{5 / 2}$ is located at 335.43 which 
is positively shifted $0.4 \mathrm{eV}$ compared to pure $\mathrm{Pd}$ due to the interaction with the carbon support. This is even further shifted to a higher value (335.54) upon addition of Ir and $\mathrm{Ni}$. It is noteworthy that some Pd exists in an oxidised form in both $\mathrm{Pd} / \mathrm{C}$ and $\mathrm{PdIrNi} / \mathrm{C}$ even though the oxide quantity is three times lower in case of PdIrNi/C. These signals that adding Ni and Ir has enhanced the Pd air stability. The majority (75\%) of nickel, however, exists in oxidised form and the remaining $25 \%$ are metallic. The Ir exists only in metallic form without any oxide unlike the finding reported by [33] who prepared PdIr/C. That could explain why the Ni presence has enhanced the air stability of both Pd and Ir.
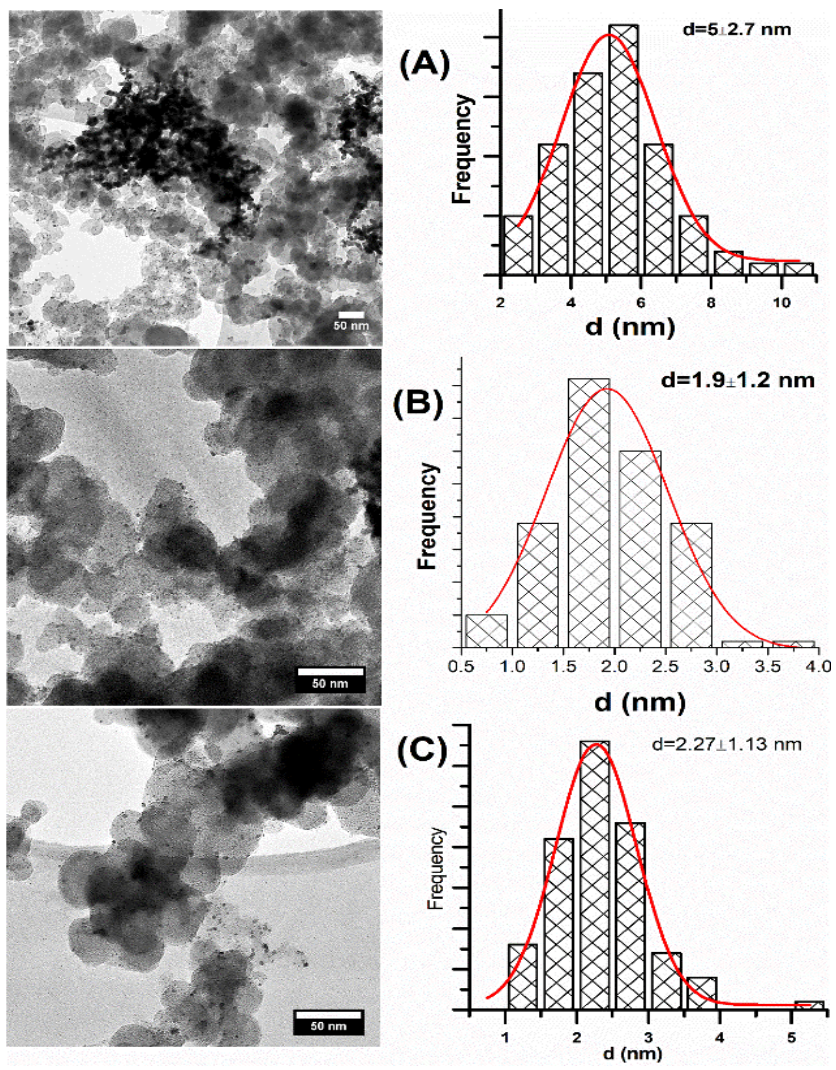

Figure 4. TEM micrographs and particle size distribution of $\mathrm{Pd} / \mathrm{C}(\mathbf{A}), \mathrm{PdIrNi} / \mathrm{C}(\mathbf{B}), \mathrm{Pd}_{4} \mathrm{Ir}_{2} \mathrm{Ni}_{1} / \mathrm{C}(\mathbf{C})$.

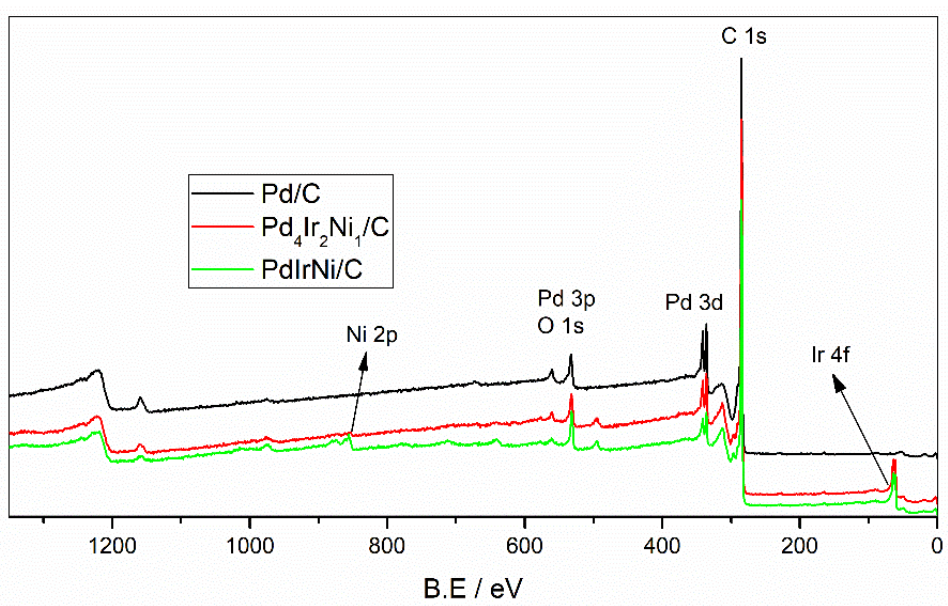

Figure 5. XPS full surveys of $\mathrm{Pd} / \mathrm{C}, \mathrm{Pd}_{4} \mathrm{Ir}_{2} \mathrm{Ni}_{1} / \mathrm{C}$, and $\mathrm{PdIrNi} / \mathrm{C}$.

Figure 7A shows the cyclic voltammetry (CV) graphs of $\mathrm{Pd} / \mathrm{C}, \mathrm{Pd}_{4} \mathrm{Ir}_{2} \mathrm{Ni}_{1} / \mathrm{C}$ and $\mathrm{PdIrNi} / \mathrm{C}$ in $1 \mathrm{M} \mathrm{KOH}$ recorded at $50 \mathrm{mV} / \mathrm{s}$. The voltammogram of $\mathrm{Pd} / \mathrm{C}$ is typical of other $\mathrm{Pd}$ ones reported $[6,10,33,50]$. The $\mathrm{H}$ adsorption/absorption is more pronounced on the trimetallic samples while it is largely suppressed on the $\mathrm{Pd} / \mathrm{C}$ due to the capacity of $\mathrm{Pd}$ to 
absorb hydrogen into its core structure instead of undergoing surface reaction. Considering PdIrNi and $\mathrm{Pd}_{4} \mathrm{Ir}_{2} \mathrm{Ni}_{1}$, Ir behaves similarly to Pt since it adsorbs $\mathrm{H}$ on its surface $[6,33]$. Therefore, the higher current noted around $-600 \mathrm{mV}$ is ascribed to that process. Upon increasing the applied potential further, $\mathrm{OH}$ adsorption commences around $-300 \mathrm{mV}$. It is noteworthy that $\mathrm{Pd} / \mathrm{C}$ shows enhanced adsorption compared to the trimetallic samples, probably due to the lower capability of $\mathrm{Ir}$ and $\mathrm{Ni}$ to adsorb $\mathrm{OH}$ [33]. The $\mathrm{OH}$ adsorption is, technically, the onset of surface oxidation but it continues until the actual surface oxidation starts around $50 \mathrm{mV}$, which continues until the end of the forward scan. However, a sharp increase in the current on PdIrNi/C is noted, at the that end, which is due to $\mathrm{Ni}(\mathrm{OH})_{2}$ oxidation to $\mathrm{NiOOH}$ which is then reduced back to $\mathrm{Ni}(\mathrm{OH})_{2}$ in the reverse scan around $350 \mathrm{mV}$ [42]. The $\mathrm{Ni}(\mathrm{OH})_{2}$-associated current increase is much less on $\mathrm{Pd}_{4} \mathrm{Ir}_{2} \mathrm{Ni}_{1} / \mathrm{C}$ than that of PdIrNi/C which is probably due to the significantly lower Ni quantity in the former. Similarly, the $\mathrm{NiOOH}$-associate current decrease was noted in the reverse scan on $\mathrm{Pd}_{4} \mathrm{Ir}_{2} \mathrm{Ni}_{1} / \mathrm{C}$ for the same reason.
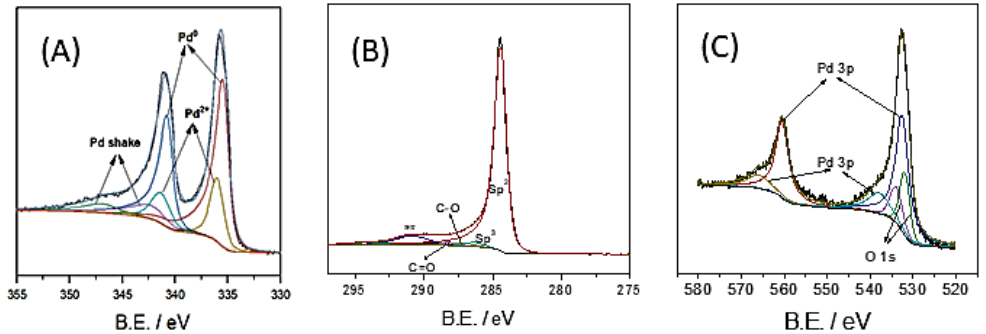

(D)
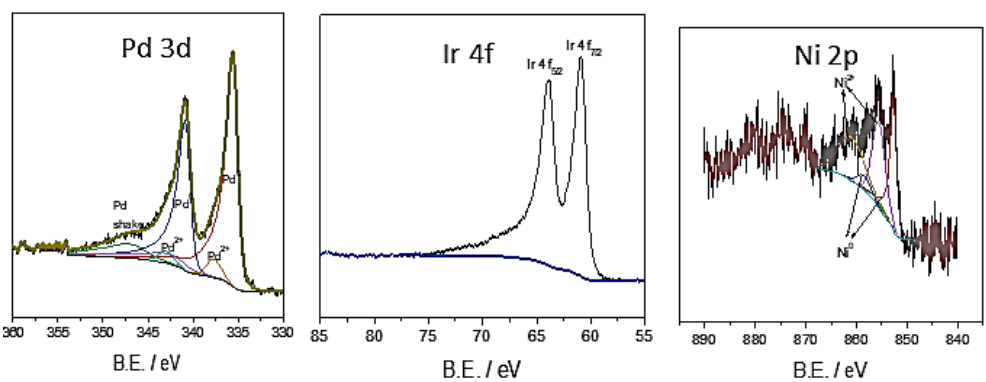

(E)

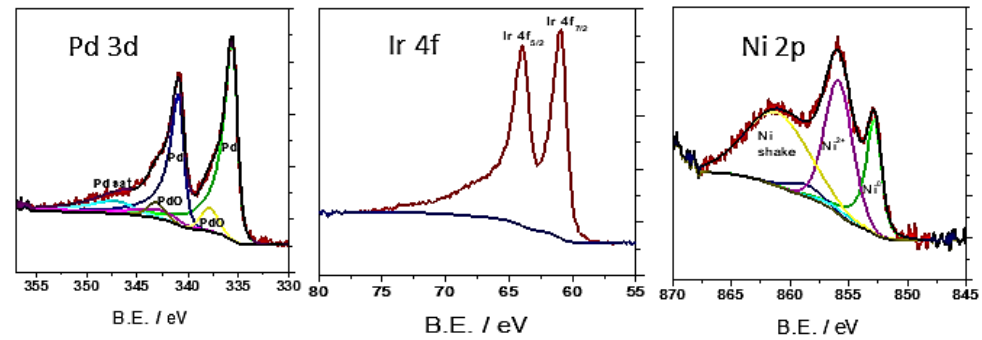

Figure 6. XPS peaks of Pd 3d (A), C 1s (B), Pd 3p + O 1s (C) in Pd/C, peaks of Pd 3d, Ni 2p, Ir 4f of $\mathrm{Pd}_{4} \mathrm{Ir}_{2} \mathrm{Ni}_{1} / \mathrm{C}(\mathbf{D})$ and PdIrNi/C (E).

After adding ethanol to $\mathrm{KOH}$ (Figure 7B), the $\mathrm{H}_{\mathrm{ads}}$ /abs peak was largely suppressed by the ethanol adsorption. At slightly higher potential $(-500,-400 \mathrm{mV}), \mathrm{OH}$ adsorption commences, facilitating the oxidation of adsorbed ethoxy species, releasing an increasing current with increasing the applied potential (increasing the adsorbed $\mathrm{OH}$ ). The single C-supported Ir shows no activity towards EOR according to [6]. However, in the same article, adding Ir to Pd/C enhanced the EOR kinetics which the authors attributed to water activation. This trend continues until Pd surface oxidation occurs at $-50 \mathrm{mV}$ for PdIrNi/C and $+50 \mathrm{mV}$ for $\mathrm{Pd} / \mathrm{C}$. A similar phenomenon is noted on $\mathrm{Pd}_{4} \mathrm{Ir}_{2} \mathrm{Ni}_{1} / \mathrm{C}$. Above such potentials, no more $\mathrm{OH}$ is adsorbed on $\mathrm{Pd}$ as the $\mathrm{Pd}$ sites are oxidised which decreases the overall current. It is noteworthy that the forward current density obtained with PdIrNi/C 
and $\mathrm{Pd}_{4} \mathrm{Ir}_{2} \mathrm{Ni}_{1} / \mathrm{C}$ is significantly less than that of $\mathrm{Pd} / \mathrm{C}$. This is the opposite of the expected benefits of $\mathrm{Ni}[41,51,52]$ and $\mathrm{Ir}[2,6,53]$ upon their individual addition to $\mathrm{Pd} / \mathrm{C}$ towards EOR. As for the reverse scan of $\mathrm{Pd} / \mathrm{C}$, it can be noted that there are two small shoulder peaks between 300 and $100 \mathrm{mV}$ and one highly intense peak at $-150 \mathrm{mV}$. The latter is usually observed and attributed to removing the incompletely oxidised species from Pd active sites. Shoulder peaks are reported in the literature and are ascribed to the removal of reaction intermediates on the Pd surface due the dynamic stirring of the solution. The reverse peak is very broad on $\mathrm{PdIrNi} / \mathrm{C}$ and $\mathrm{Pd}_{4} \mathrm{Ir}_{2} \mathrm{Ni}_{1} / \mathrm{C}$.
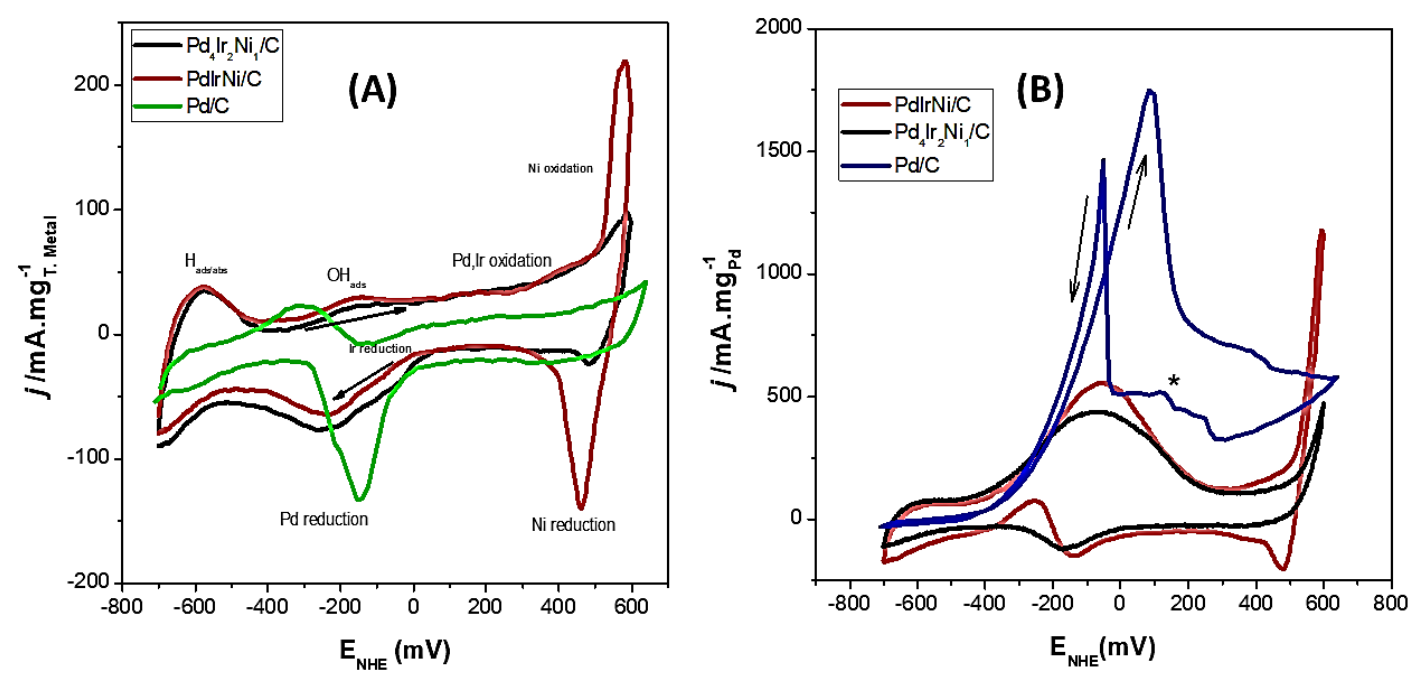

Figure 7. Cyclic voltammetry (CV) of $\mathrm{Pd} / \mathrm{C}$, $\mathrm{PdIrNi} / \mathrm{C}$, and $\mathrm{Pd}_{4} \mathrm{Ir}_{2} \mathrm{Ni}_{1} / \mathrm{C}$ in $1 \mathrm{M} \mathrm{KOH}$ at $50 \mathrm{mV} / \mathrm{s}$ vs. $\mathrm{NHE}$ in $1 \mathrm{M} \mathrm{KOH}(\mathbf{A})$ and $1 \mathrm{M} \mathrm{KOH}+\mathrm{EtOH}(\mathbf{B})\left(^{*}\right)$ unknown peaks.

Considering PdIrNi/C, it can be noted that the high current at the forward scan end $\left(1250 \mathrm{~mA} / \mathrm{mg}_{\mathrm{Pd}}\right)$ is due to $\mathrm{NiOOH}$ ethanol activating activation as was found by Barbosa et al. [54]. Comparing this value to the current value in $\mathrm{KOH}$ only $(225 \mathrm{~mA} / \mathrm{mg})$ illustrates that ethanol is oxidised by the oxidised Ni species. However, it is noteworthy that the upward going current density suggests that EOR on $\mathrm{NiOOH}$ has recently started at approximately $500 \mathrm{mV}$ as shown in Figure 7B. A current density peak could be expected at higher positive potential as was found by [54] who also found two reduction peaks in the reverse scan, one of which was due to $\mathrm{NiOOH}$ backward reduction to $\mathrm{Ni}(\mathrm{OH})_{2}$. A similar conclusion was obtained regarding EOR on $\mathrm{Ni}(\mathrm{OH})_{2}$ microspheres by Lidasan et al. [55]. A further similar conclusion about $\mathrm{NiO}$ was obtained by Amin et al. [56].The overall oxidation current of PdIrNi/C is lower than that of $\mathrm{Pd} / \mathrm{C}$. This could be due to the inactivity of Ir and $\mathrm{Ni}$ to ethanol oxidation while they occupy most of the PdIrNi/C near-surface layers. Additionally, the positive Pd 3d binding shift (Table 4) is suggestive of stronger bonds between $\mathrm{Pd}$ and the poisons such as $\mathrm{CO}_{\mathrm{x}}$.

To investigate the catalyst's EOR stability, 2-step chronoamperometry scan was undertaken on each catalyst (Figure 8). The first constant potential was $-0.3 \mathrm{~V}$ and was applied for $30 \mathrm{~min}$. The second was $+0.1 \mathrm{~V}$ and was applied for another $30 \mathrm{~min}$ starting immediately after the first step ended. The scans were performed in $1 \mathrm{M} \mathrm{KOH}+\mathrm{C}_{2} \mathrm{H}_{5} \mathrm{OH}$. The $-0.3 \mathrm{~V}$ potential, according to Figure 7, is located in the middle of $\mathrm{OH}$ adsorption potential window. Therefore, in Figure 8, a high tolerance for poisoning species is attained by the constant generation of adsorbed $\mathrm{OH}$ species that are capable of removing the adsorbed ethoxy. The higher current obtained for $\mathrm{Pd} / \mathrm{C}$ that is more than the two trimetallic catalysts is probably because of the $\mathrm{Pd}$ surface abundance on it. This is further proved by the higher current density of $\mathrm{Pd}_{4} \mathrm{Ir}_{2} \mathrm{Ni}_{1} / \mathrm{C}$ than PdIrNi/C because the former's surface contains Pd more than Ir and Ni combined while the latter's surface contains equivalent molar concentrations of each metal (Tables 3 and 4). Also, there is a shift to higher binding energies (approximately $+0.1 \mathrm{eV}$ ) of Pd $3 \mathrm{~d}$ according to the XPS (Table 4). Such a shift to a higher binding energy 
could be a negative indication of lower catalytic performance. A higher bonding strength existing between $\mathrm{Pd}$ sites and poisoning species on the trimetallic samples could present higher activation barriers of EOR compared to Pd/C. At $-0.1 \mathrm{~V}$, however, the initially remarkable current density, on $\mathrm{Pd} / \mathrm{C}$, decays rapidly with the time. The quick current deterioration is probably because of lacking $\mathrm{OH}$ species (Figures 6 and 7) on the catalyst surface to remove the poisoning species which leads to permanent losses of Pd active sites. Nonetheless, the trimetallic samples achieve identical CA current densities-which are much less than $\mathrm{Pd} / \mathrm{C}$-at $+0.1 \mathrm{~V}$. That is once again because of less $\mathrm{Pd}$ surface presence. It is, also, noteworthy, that both catalysts achieve identical current density in the voltammogram forward scan (Figure 7) which is probably why they achieve identical CA current densities. However, both of them achieve stable current compared to $\mathrm{Pd} / \mathrm{C}$ which is due the $\mathrm{Ir}$ and $\mathrm{Ni}$ potential to generate oxygen species that could remove the ethoxy from Pd active sites.

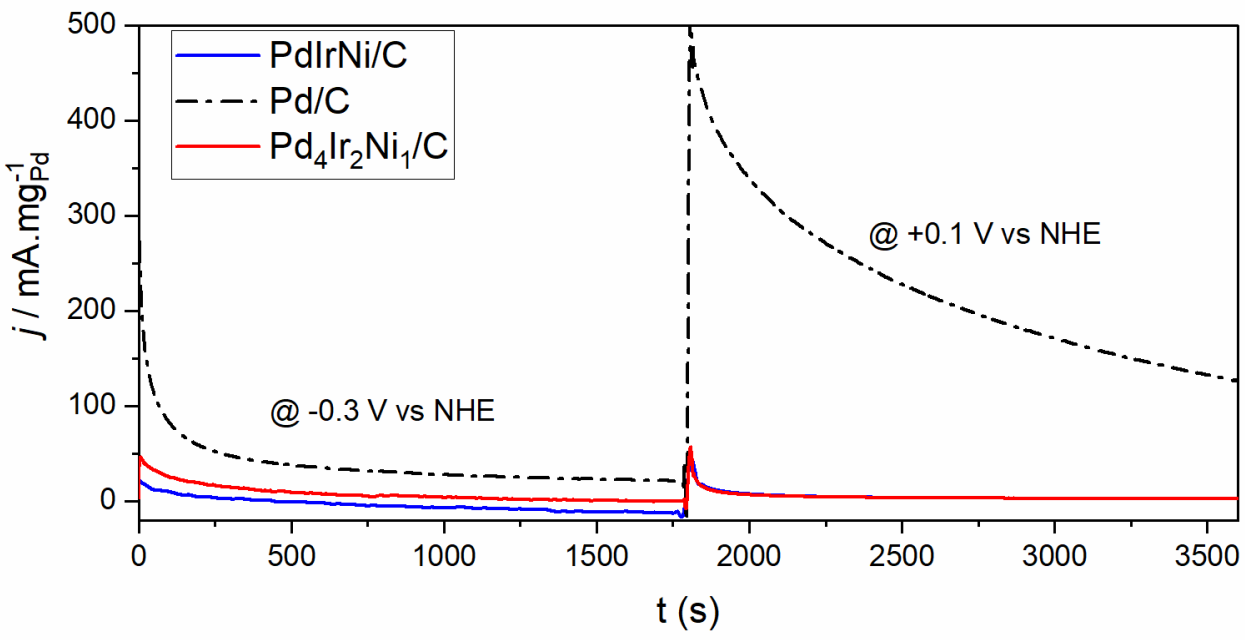

Figure 8. Step chronoamperometry (CA) scans of $\mathrm{Pd} / \mathrm{C} \mathrm{Pd}_{4} \mathrm{Ir}_{2} \mathrm{Ni}_{1} / \mathrm{C}$ and $\mathrm{PdIrNi} / \mathrm{C}$ in $1 \mathrm{M} \mathrm{KOH}+\mathrm{EtOH}$ at $-0.3 \mathrm{~V}$ and $+0.1 \mathrm{~V}$ vs. NHE.

\section{Discussion}

The electrochemical test results show that both of the currently prepared PdIrNi/C samples have underperformed their monometallic counterpart towards EOR even though their physiochemical characteristics predict otherwise. Nonetheless, the results have been reproduced three times for each catalyst and the same performance was obtained that demonstrates such outcomes are reproducible. There are no solid explanations or understanding of what is actually happening with these samples during EOR. The baseline interpretation is that both trimetallic surfaces contain less Pd active sites than Pd/C which is not entirely inaccurate according to the EDX and XPS results although the exact in situ reduction of Pd active sites is unknown. Moreover, the exact consequent physical and electrochemical impact on the EOR mechanism is also unknown. More advanced analytical and in situ studies of EOR could reveal information that is not known, presently. Nonetheless, there is a previous PdIrNi/C report on EOR by Shen et al. [4] in which it outperformed its monometallic Pd and bimetallic PdIr and PdNi counterparts. The synthesis method, physiochemical characteristics, and testing conditions in the current work and [4] are similar to a large extent. The only notable differences are the stabilising agent and Ir and Ni content used. They used a potassium citrate as a stabilising agent, while $\mathrm{KBr}$ was used in this work. Since $\mathrm{KBr}$ was also used as a stabiliser in the synthesis of C-supported PdAgNi [57] that outperformed the monometallic Pd/C for EOR, it is unlikely to have a detrimental effect during EOR on PdIrNi. Another reason to think $\mathrm{KBr}$ does not have a negative effect is that it was, also, applied for C-supported PdAuNi that outperformed its monometallic Pd counterpart for direct borohydride elctrooxidation [58]. The other notable difference is the atomic ratio of $\mathrm{Pd}$, Ir, and Ni which is 7:1:12 in [4] while the ratios in this work are 1:1:1 and 4:2:1. The Ir content in their sample is much lower than 
that at the current two samples and the opposite is true about Ni. How such different $\mathrm{Ni}$ and Ir contents might have impacted PdIrNi EOR performance is beyond the scope of this work.

\section{Conclusions}

Trimetallic C-supported PdIrNi/C nanoparticles have been successfully prepared by $\mathrm{NaBH}_{4}$ co-reduction. The XRD, TEM, EDX, and XPS results prove the formation of alloyed and well-dispersed $(<3 \mathrm{~nm}) \mathrm{PdIrNi} / \mathrm{C}$ nanoparticles in both trimetallic samples existing in proportionate metallic state (apart from Ni). However, both trimetallic samples have underperformed their monometallic counterpart for ethanol electrooxidation. Given the good physicochemical characteristics, the exact mechanism through which PdIrNi catalysts have underperformed their Pd counterpart towards EOR is still unknown. Further analytical and in situ studies might shed more light on that. Another finding is that Ni is active for EOR but at significant overpotential compared to Pd, unfortunately.

Author Contributions: Conceptualization, A.E. and J.M.; methodology, A.E.; software, A.E.; validation, J.M., A.E.; investigation, A.E.; resources, J.M.; data curation, A.E.; writing-original draft preparation, A.E. and H.M.M.; writing-review and editing, H.M.M. and J.M. All authors have read and agreed to the published version of the manuscript.

Funding: Ahmed Elsheikh is grateful for the financial support of Newton-Mosharafa Fund (Reference no. NMJ8/15) of his Ph.D.

Acknowledgments: XPS data collection was performed at the EPSRC National Facility for XPS ('HarwellXPS'), operated by Cardiff University and UCL, under contract No. PR16195.

Conflicts of Interest: The authors declare there is no conflict of interest related to this work.

\section{References}

1. Monyoncho, E.A.; Steinmann, S.N.; Michel, C.; Baranova, E.A.; Woo, T.K.; Sautet, P. Ethanol Electro-oxidation on Palladium Revisited Using Polarization Modulation Infrared Reflection Absorption Spectroscopy (PM-IRRAS) and Density Functional Theory (DFT): Why Is It Difficult To Break the C-C Bond? ACS Catal. 2016, 6, 4894-4906. [CrossRef]

2. Shen, S.Y.; Guo, Y.G.; Wei, G.H.; Luo, L.X.; Li, F.; Zhang, J.L. A perspective on the promoting effect of Ir and Au on Pd toward the ethanol oxidation reaction in alkaline media. Front. Energy 2018, 12, 501-508. [CrossRef]

3. Mohamed, I.M.A.; Khalil, K.A.; Mousa, H.M.; Barakat, N.A.M. Ni/Pd-Decorated Carbon NFs as an Efficient Electrocatalyst for Methanol Oxidation in Alkaline Medium. J. Electron. Mater. 2017, 46, 265-273. [CrossRef]

4. Shen, S.; Zhao, T.S.; Xu, J.; Li, Y. High performance of a carbon supported ternary PdIrNi catalyst for ethanol electro-oxidation in anion-exchange membrane direct ethanol fuel cells. Energy Environ. Sci. 2011, 4, 1428. [CrossRef]

5. Moraes, L.P.R.; Matos, B.R.; Radtke, C.; Santiago, E.I.; Fonseca, F.C.; Amico, S.C.; Malfatti, C.F. Synthesis and performance of palladium-based electrocatalysts in alkaline direct ethanol fuel cell. Int. J. Hydrogen Energy 2016, 41, 6457-6468. [CrossRef]

6. Neto, A.O.; Da Silva, S.G.; Buzzo, G.S.; De Souza, R.F.B.; Assumpção, M.H.M.T.; Spinacé, E.V.; Silva, J.C.M. Ethanol electrooxidation on PdIr/C electrocatalysts in alkaline media: Electrochemical and fuel cell studies. Ionics 2015, 21, 487-495. [CrossRef]

7. Cronin, J.; Anandarajah, G.; Dessens, O. Climate change impacts on the energy system: A review of trends and gaps. Clim. Chang. 2018, 151, 79-93. [CrossRef] [PubMed]

8. Kamarudin, M.Z.F.; Kamarudin, S.K.; Masdar, M.S.; Daud, W.R.W. Review: Direct ethanol fuel cells. Int. J. Hydrogen Energy 2013, 38, 9438-9453. [CrossRef]

9. Brouzgou, A.; Podias, A.; Tsiakaras, P. PEMFCs and AEMFCs directly fed with ethanol: A current status comparative review. J. Appl. Electrochem. 2013, 43, 119-136. [CrossRef]

10. Chen, W.; Zhang, Y.; Wei, X. Catalytic performances of PdNi/MWCNT for electrooxidations of methanol and ethanol in alkaline media. Int. J. Hydrogen Energy 2015, 40, 1154-1162. [CrossRef]

11. Calvillo, L.; Celorrio, V.; Moliner, R.; Garcia, A.B.; Caméan, I.; Lazaro, M.J. Comparative study of Pt catalysts supported on different high conductive carbon materials for methanol and ethanol oxidation. Electrochim. Acta 2013, 102, 19-27. [CrossRef]

12. Chen, L.Y.; Chen, N.; Hou, Y.; Wang, Z.C.; Lv, S.H.; Fujita, T.; Jiang, J.H.; Hirata, A.; Chen, M.W. Geometrically Controlled Nanoporous PdAu Bimetallic Catalysts with Tunable Pd/Au Ratio for Direct Ethanol Fuel Cells. ACS Catal. 2013, 3, 1220-1230. [CrossRef]

13. Ma, L.; Chu, D.; Chen, R. Comparison of ethanol electro-oxidation on Pt/C and Pd/C catalysts in alkaline media. Int. J. Hydrogen Energy 2012, 37, 11185-11194. [CrossRef]

14. O'Hayre, R.; Cha, S.W.; Colella, W.; Prinz, F.B. Chapter 14: Environmental Impact of Fuel Cells. In Fuel Cell Fundamentals; John Wiley \& Sons, Inc.: Hoboken, NJ, USA, 2016; pp. 481-516. [CrossRef] 
15. Antolini, E.; Gonzalez, E.R. Alkaline direct alcohol fuel cells. J. Power Sources 2010, 195, 3431-3450. [CrossRef]

16. Pérez-Rodríguez, S.; Pastor, E.; Lázaro, M.J. Electrochemical behavior of the carbon black Vulcan XC-72R: Influence of the surface chemistry. Int. J. Hydrogen Energy 2018, 43, 7911-7922. [CrossRef]

17. Da Silva, E.L.; Ortega Vega, M.R.; Correa, P.D.S.; Cuña, A.; Tancredi, N.; Malfatti, C.D.F. Influence of activated carbon porous texture on catalyst activity for ethanol electro-oxidation. Int. J. Hydrogen Energy 2014, 39, 14760-14767. [CrossRef]

18. Elsheikh, A.; Martins, V.L.V.L.; McGregor, J. Influence of physicochemical characteristics of carbon supports on Pd ethanol oxidation catalysts. Energy Procedia 2018, 151, 79-83. [CrossRef]

19. Antolini, E. Carbon supports for low-temperature fuel cell catalysts. Appl. Catal. B Environ. 2009, 88, 1-24. [CrossRef]

20. Carmo, M.; Brandalise, M.; Neto, A.O.; Spinacé, E.V.; Taylor, A.D.; Linardi, M.; Rocha Poço, J.G.; Rocha Poo, J.G. Enhanced activity observed for sulfuric acid and chlorosulfuric acid functionalized carbon black as PtRu and PtSn electrocatalyst support for DMFC and DEFC applications. Int. J. Hydrogen Energy 2011, 36, 14659-14667. [CrossRef]

21. Jurzinsky, T.; Gomez-Villa, E.D.; Kübler, M.; Bruns, M.; Elsässer, P.; Melke, J.; Scheiba, F.; Cremers, C. Functionalization of multi-walled carbon nanotubes with indazole. Electrochim. Acta 2019, 298, 884-892. [CrossRef]

22. Yang, C.; Hu, X.; Wang, D.; Dai, C.; Zhang, L.; Jin, H.; Agathopoulos, S. Ultrasonically treated multi-walled carbon nanotubes (MWCNTs) as PtRu catalyst supports for methanol electrooxidation. J. Power Sources 2006, 160, 187-193. [CrossRef]

23. Kanninen, P.; Borghei, M.; Hakanpää, J.; Kauppinen, E.I.; Ruiz, V.; Kallio, T. Temperature dependent performance and catalyst layer properties of PtRu supported on modified few-walled carbon nanotubes for the alkaline direct ethanol fuel cell. J. Electroanal. Chem. 2017, 793, 48-57. [CrossRef]

24. Wang, Y.J.; Fang, B.; Li, H.; Bi, X.T.; Wang, H. Progress in modified carbon support materials for Pt and Pt-alloy cathode catalysts in polymer electrolyte membrane fuel cells. Prog. Mater. Sci. 2016, 82, 445-498. [CrossRef]

25. Sheikh, A.M.; Correa, P.S.; Leal da Silva, E.; Savaris, I.D.; Amico, S.C.; Malfatti, C.F.; Silva, E.L.; Savaris, I.D.; Amico, S.C.; Malfatti, C.F. Energy conversion using pd-based catalysts in direct ethanol fuel cell. Renew. Energy Power Qual. J. 2013, 1, 342-345. [CrossRef]

26. Sheikh, A.M.; Silva, E.L.; Correa, P.S.; Menezes, T.L. The Effect of Adding Ni and Sn to Pd Catalysts on the Direct Ethanol Fuel Cell Performance. In Proceedings of the International Conference on Energy, Environment and Materials Engineering (EEME 2014), Shenzhen, China, 22-23 February 2014.

27. Sheikh, A.M.; Silva, E.L.; Moares, L.; Antonini, L.M.; Abellah, M.Y.; Malfatti, C.F. Pd-based Catalysts for Ethanol Oxidation in Alkaline Electrolyte. Am. J. Min. Metall. 2014, 2, 64-69. [CrossRef]

28. Martins, M.; Šljukić, B.; Metin, Ö.; Sevim, M.; Sequeira, C.A.C.; Şener, T.; Santos, D.M.F. Bimetallic PdM (M = Fe, Ag, Au) alloy nanoparticles assembled on reduced graphene oxide as catalysts for direct borohydride fuel cells. J. Alloys Compd. 2017, 718, 204-214. [CrossRef]

29. Chen, T.; Rodionov, V.O. Controllable Catalysis with Nanoparticles: Bimetallic Alloy Systems and Surface Adsorbates. ACS Catal. 2016, 6, 4025-4033. [CrossRef]

30. Zhu, C.; Wen, D.; Oschatz, M.; Holzschuh, M.; Liu, W.; Herrmann, A.-K.K.; Simon, F.; Kaskel, S.; Eychmüller, A. Kinetically controlled synthesis of PdNi bimetallic porous nanostructures with enhanced electrocatalytic activity. Small 2015, 11, 1430-1434. [CrossRef]

31. Cai, J.; Zeng, Y.; Guo, Y. Copper@palladium-copper core-shell nanospheres as a highly effective electrocatalyst for ethanol electro-oxidation in alkaline media. J. Power Sources 2014, 270. [CrossRef]

32. Su, P.P.-C.; Chen, H.-S.H.; Chen, T.T.-Y.; Liu, C.-W.C.; Lee, C.-H.; Lee, J.-F.; Chan, T.-S.; Wang, K.-W. Enhancement of electrochemical properties of $\mathrm{Pd} / \mathrm{C}$ catalysts toward ethanol oxidation reaction in alkaline solution through $\mathrm{Ni}$ and Au alloying. Int. J. Hydrogen Energy 2013, 38, 4474-4482. [CrossRef]

33. Assumpção, M.H.M.T.; Da Silva, S.G.; De Souza, R.F.B.; Buzzo, G.S.; Spinacé, E.V.; Santos, M.C.; Neto, A.O.; Silva, J.C.M. Investigation of PdIr/C electrocatalysts as anode on the performance of direct ammonia fuel cell. J. Power Sources 2014, 268, 129-136. [CrossRef]

34. Geraldes, A.N.; da Silva, D.F.; e Silva, L.G.D.A.; Spinacé, E.V.; Neto, A.O.; dos Santos, M.C. Binary and ternary palladium based electrocatalysts for alkaline direct glycerol fuel cell. J. Power Sources 2015, 293, 823-830. [CrossRef]

35. Ulas, B.; Caglar, A.; Sahin, O.; Kivrak, H. Composition dependent activity of PdAgNi alloy catalysts for formic acid electrooxidation. J. Colloid Interface Sci. 2018, 532, 47-57. [CrossRef]

36. Dutta, A.; Datta, J. Outstanding Catalyst Performance of PdAuNi Nanoparticles for the Anodic Reaction in an Alkaline Direct Ethanol (with Anion-Exchange Membrane) Fuel Cell. J. Phys. Chem. C 2012, 116, 25677-25688. [CrossRef]

37. Shang, C.; Hong, W.; Wang, J.; Wang, E. Carbon supported trimetallic nickel-palladium-gold hollow nanoparticles with superior catalytic activity for methanol electrooxidation electrooxidation. J. Power Sources 2015, 285, 12-15. Available online: https://www-sciencedirect-com.sheffield.idm.oclc.org/science/article/pii/S037877531500508X (accessed on 11 May 2019). [CrossRef]

38. Sharma, G.; Kumar, D.; Kumar, A.; Al-Muhtaseb, H.; Pathania, D.; Naushad, M.; Tessema Mola, G. Revolution from monometallic to trimetallic nanoparticle composites, various synthesis methods and their applications: A review. Mater. Sci. Eng. C 2017, 71, 1216-1230. [CrossRef] [PubMed] 
39. Zhu, W.; Ke, J.; Wang, S.-B.; Ren, J.; Wang, H.-H.; Zhou, Z.-Y.; Si, R.; Zhang, Y.-W.; Yan, C.-H. Shaping Single-Crystalline Trimetallic Pt-Pd-Rh Nanocrystals toward High-Efficiency C-C Splitting of Ethanol in Conversion to CO $_{2}$. ACS Catal. 2015, 5, 1995-2008. [CrossRef]

40. Beyhan, S.; Léger, J.-M.; Kadırgan, F. Understanding the influence of Ni, Co, Rh and Pd addition to PtSn/C catalyst for the oxidation of ethanol by in situ Fourier transform infrared spectroscopy. Appl. Catal. B Environ. 2014, 144, 66-74. [CrossRef]

41. Feng, Y.; Bin, D.; Yan, B.; Du, Y.; Majima, T.; Zhou, W. Porous bimetallic PdNi catalyst with high electrocatalytic activity for ethanol electrooxidation. J. Colloid Interface Sci. 2017, 493, 190-197. [CrossRef] [PubMed]

42. Dutta, A.; Datta, J. Energy efficient role of Ni/NiO in PdNi nano catalyst used in alkaline DEFC. J. Mater. Chem. A 2014, 2, 3237. [CrossRef]

43. Henrique, R.S.; Ayoub, J.M.S.; Piasentin, R.M.; Linardi, M.; Santos, M.C. Preparation of Pt/C- $\mathrm{In}_{2} \mathrm{O}_{3}$. SnO $\mathrm{Sn}_{2}$ Electrocatalysts by Borohydride Reduction Process for Ethanol Electro-Oxidation. Int. J. Electrochem. Sci. 2012, 7, 2036-2046. [CrossRef]

44. Neto, A.O.; Tusi, M.M.; De Oliveira Polanco, N.S.; Da Silva, S.G.; Coelho Dos Santos, M.; Spinacé, E.V. PdBi/C electrocatalysts for ethanol electro-oxidation in alkaline medium. Int. J. Hydrogen Energy 2011, 36, 10522-10526. [CrossRef]

45. Leng, Y. X-Ray Spectroscopy for Elemental Analysis. In Materials Characterization; John Wiley \& Sons, Ltd.: Chichester, UK; pp. 171-196. [CrossRef]

46. Amin, R.S.; Hameed, R.M.A.; El-Khatib, K.M.; Youssef, M.E.; Abdel Hameed, R.M.; El-Khatib, K.M.; Elsayed Youssef, M.; Hameed, R.M.A.; El-Khatib, K.M.; Youssef, M.E. Electrocatalytic activity of nanostructured Ni and Pd-Ni on Vulcan XC-72R carbon black for methanol oxidation in alkaline medium. Int. J. Hydrogen Energy 2014, 39, 2026-2041. [CrossRef]

47. Hermann, K. Appendix E: Parameter Tables of Crystals. Crystallogr. Surf. Struct. 2011, 265-266. [CrossRef]

48. Zhu, F.; Ma, G.; Bai, Z.; Hang, R.; Tang, B.; Zhang, Z.; Wang, X. High activity of carbon nanotubes supported binary and ternary Pd-based catalysts for methanol, ethanol and formic acid electro-oxidation. J. Power Sources 2013, 242, 610-620. [CrossRef]

49. Suo, Y.; Hsing, I. Synthesis of bimetallic PdAu nanoparticles for formic acid oxidation. Electrochim. Acta 2011, 56, 2174-2183. [CrossRef]

50. Chen, A.; Ostrom, C. Palladium-Based Nanomaterials: Synthesis and Electrochemical Applications. Chem. Rev. 2015, 115, 11999-12044. [CrossRef]

51. Ramulifho, T.; Ozoemena, K.I.; Modibedi, R.M.; Jafta, C.J.; Mathe, M.K. Fast microwave-assisted solvothermal synthesis of metal nanoparticles (Pd, Ni, Sn) supported on sulfonated MWCNTs: Pd-based bimetallic catalysts for ethanol oxidation in alkaline medium. Electrochim. Acta 2012, 59, 310-320. [CrossRef]

52. Obradović, M.D.; Stančić, Z.M.; Lačnjevac, U.Č.; Radmilović, V.V.; Gavrilović-Wohlmuther, A.; Radmilović, V.R.; Gojković, S.L. Electrochemical oxidation of ethanol on palladium-nickel nanocatalyst in alkaline media. Appl. Catal. B Environ. 2016, 189, 110-118. [CrossRef]

53. Shen, S.Y.; Zhao, T.S.; Xu, J.B. Carbon-supported bimetallic PdIr catalysts for ethanol oxidation in alkaline media. Electrochim. Acta 2010, 55, 9179-9184. [CrossRef]

54. Barbosa, A.F.B.; Oliveira, V.L.; Van Drunen, J.; Tremiliosi-Filho, G. Ethanol electro-oxidation reaction using a polycrystalline nickel electrode in alkaline media: Temperature influence and reaction mechanism. J. Electroanal. Chem. 2015, 746, 31-38. [CrossRef]

55. Lidasan, J.J.B.; Del Rosario, J.A.D.; Ocon, J.D. Ethanol electrooxidation on phase-and morphology-controlled ni(Oh)2 microspheres. Catalysts 2020, 10, 740. [CrossRef]

56. Amin, S.; Tahira, A.; Solangi, A.R.; Mazzaro, R.; Ibupoto, Z.H.; Fatima, A.; Vomiero, A. Functional Nickel Oxide Nanostructures for Ethanol Oxidation in Alkaline Media. Electroanalysis 2020, 32, 1052-1059. [CrossRef]

57. Elsheikh, A.; McGregor, J. Synthesis and characterization of pdagni/c trimetallic nanoparticles for ethanol electrooxidation. Nanomaterials 2021, 11, 2244. [CrossRef] [PubMed]

58. Elsheikh, A.M.A.; Backović, G.; Oliveira, R.C.P.; Sequeira, C.A.C.; McGregor, J.; Šljukić, B.; Santos, D.M.F. Carbon-supported trimetallic catalysts (Pdauni/c) for borohydride oxidation reaction. Nanomaterials 2021, 11, 1441. [CrossRef] 